\title{
Alforrias e tamanho das posses possibilidades de liberdade em pequenas, médias e grandes propriedades do sudeste escravista (século XIX)*
}

\section{Manumission and size of the slave stocks

\author{
possibilities of freedom in small,
} medium and large Southeast slave farms $\left(19^{\text {th }}\right.$ century)}

\author{
JONIS FREIRE \\ Doutor em História pela Unicamp \\ Professor do Mestrado em História da Universidade Salgado de Oliveira \\ Rua Marechal Deodoro, 217, 2º andar, Centro, Niterói/RJ, 24030-060 \\ jonisfreire@yahoo.com.br
}

\begin{abstract}
RESUMO O objetivo deste artigo é empreender uma análise acerca das possibilidades de alforria em pequenas, médias e grandes posses de escravos, localizadas em Juiz de Fora (MG), Zona da Mata Mineira, no século XIX. A partir do intercruzamento de fontes concernentes a três grandes famílias possuidoras de escravos, pudemos perceber que a maioria das alforrias distribuídas aos cativos não se deu necessariamente por meio da carta de alforria, sendo também muito importantes as manumissões em testamento e no decorrer do inventário, além das distribuídas em outras situações. Percebemos que os três grandes proprietários de cativos estudados alforriaram proporcionalmente mais cativos do que os pequenos e médios. Houve, portanto, em Juiz de Fora, uma correlação inversa entre o tamanho das posses e as percentagens de alforria "concedidas" por pequenos, médios e grandes senhores escravistas.
\end{abstract}

Artigo recebido em: 18/12/2009. Aprovado em: 23/09/2010. 
Palavras-chave alforrias, posses de escravos, escravidão, Juiz de Fora

ABSTRACT This article aims to undertake an analysis of the possibilities of liberation in small, medium and large stocks of slaves, located in Juiz de Fora (MG), Zona da Mata Mineira, in the Nineteenth century. Through intercrossed sources concerning the three major families of slave holders, we realized that most manumissions distributed to the captives was not necessarily by the letter of enfranchisement, and also very important in the manumissions and will during the inventory, distributed in addition to other situations. We realized that those three major owners of the captive studied manumit proportionately more than the small and medium. There was, therefore, in Juiz de Fora, and elsewhere in Southeast slave, an inverse correlation between the size of possessions and the percentages of liberation distributed for small, medium and large slave masters.

Keywords manumissions, slave stocks, slavery, Juiz de Fora

Neste trabalho faremos uma discussão a respeito das possibilidades de manumissão de acordo com o tamanho das posses (pequenas, médias ou grandes). Para tanto, nosso recorte geográfico é a atual cidade de Juiz de Fora, que no decorrer do século XIX se constituiu como uma grande plantation produtora de café e também como a maior possuidora de cativos em Minas Gerais.

Buscamos também, por meio de análises comparativas com outras localidades do sudeste escravista, perceber se havia uma correlação inversa entre as porcentagens de alforria e o tamanho das posses escravistas. Realizamos um estudo baseado nas posses de três famílias senhoriais, quais sejam os Dias Tostes, os Paula Lima e os Barbosa Lage. O interesse em estudar estas famílias se deu em virtude do fato de que as mesmas possuíram grandes extensões de terras e contingente escravo, elevado prestígio político e social, o que as coloca, a nosso ver, como representativas no que diz respeito ao que era ser um grande senhor escravista na região estudada. O critério de escolha destes senhores se fez também pela maior variedade de registros sobre suas escravarias, o que possibilitou o intercruzamento de fontes variadas. ${ }^{1}$ Mas antes de entrarmos na análise destas posses vamos nos ater a alguns debates historiográficos, sobre as alforrias, que norteiam as questões desenvolvidas neste artigo.

1 A esse respeito conferir: FREIRE, Jonis. Escravidão e família escrava na Zona da Mata Mineira oitocentista. São Paulo: Universidade Estadual de Campinas, 2009. (História, Tese de Doutorado). 


\section{As Alforrias na historiografia e o intercruzamento de fontes}

"'A liberdade', disse um pastor negro, 'queimava no coração do negro muito antes que a liberdade tivesse nascido'". ${ }^{2}$ Foi utilizando-se desta e de outras aspirações expressas pelos cativos, em período posterior à Guerra Civil americana, que Eric Foner procurou tecer algumas considerações sobre o significado da liberdade para escravos e libertos nos Estados Unidos.

Embora esse excerto diga respeito às expectativas de um afro-americano, o desejo latente, quase vital, de liberdade foi algo esperado pelos escravizados em todas as regiões em que estiveram presentes, e no Brasil não foi diferente. Certamente os escravos tiveram possibilidades de obter para si e suas famílias, por meio de sua atuação, ganhos dentro do sistema escravista, sempre oscilando entre a autonomia e a dependência. ${ }^{3}$

A obtenção das manumissões contou com as estratégias dos cativos, seja por meio da busca por sua liberdade nos tribunais, ou estabelecendo relações mais próximas com seus senhores; as vontades e expectativas dos cativos foram de fundamental importância para a sua liberdade e a de seus familiares. Tarcísio Botelho ressaltou que no caso do Brasil "é imprescindível compreender o processo como se dava à concessão de alforrias e o papel dos alforriados em nossa sociedade caso queiramos compreendê-la adequadamente". ${ }^{4}$

No Brasil, Peter Eisenberg, pesquisando cartas de alforria registradas entre 1798 e 1888 nos cartórios de Campinas (SP), analisou alguns aspectos deste instrumento legal que documentava a passagem dos indivíduos da condição de escravo para a de livre, sugerindo questões que poderiam ser verificadas por meio de pesquisas sobre as alforrias. Naquele momento, o pesquisador já se preocupava e perguntava se "a carta de alforria é uma fonte suficiente para estudar o ato de alforriar, e se não existe outra documentação também importante". 5

Esse questionamento decorreu, dentre outros motivos, pela preocupação de Eisenberg em saber até que ponto era obrigatório o reconhecimento desta prática:

Uma questão importante é saber se as cartas são completas como fonte para retratar a importância do ato da alforria. A legalidade do ato no Brasil remonta pelo menos às ordenações Filipinas (1603) e sobrevivem cartas de alforria com data de 1684. Mas até que ponto era obrigatório registrar a carta de alforria?

2 FONER, Eric. O significado da liberdade. Revista Brasileira de História, São Paulo, v.8, n.16, p.10, mar/ago 1988.

3 A historiografia nacional e internacional sobre o tema é bastante vasta e instigante. Contudo, neste artigo vamos dialogar com uma bibliografia que, a par de alguma omissão, pode nos ajudar a atingir os objetivos centrais deste texto.

4 BOTELHO, Tarcísio Rodrigues. As alforrias em Minas Gerais no século XIX. Varia Historia, Belo Horizonte, n.23, p.62, jul/2000.

5 EISENBERG, Peter. Homens esquecidos: escravos e trabalhadores livres no Brasil, séculos XVIII e XIX. Campinas: Editora da Unicamp, 1989, p.246. 
Somente em 1860, apenas duas décadas antes da abolição, foi aprovada uma lei que obrigou os senhores a registrar em escritura pública a compra e a venda de escravos cujo valor excedesse $200 \$ 000$, mas não há menção de registro obrigatório de alforrias. Conforme a Lei do Ventre Livre, Artigo 4, foram garantidos os direitos do escravo de acumular um pecúlio, transferível por herança a seus filhos, e de ter seu valor de alforria estabelecido pela justiça. Essa lei também limitava o tempo de prestação de serviços - que, antes, muitas vezes, ia até a morte do senhor - a sete anos e isentava as alforrias de 'quaisquer direitos, emolumentos ou despesas'. ${ }^{6}$

Eisenberg destacou outros tipos de fontes que deveriam ser consultadas, com o intuito de melhor conhecer as práticas de manumissão, bem como o número das mesmas. "Que outro tipo de documentação existe para estudar a alforria?" 7

Respondendo ao seu próprio questionamento, o pesquisador apontou uma série de documentos para o estudo das alforrias. Dentre eles, os registros paroquiais de batismos de escravos para o período no qual a criança ainda seguia a condição da mãe (partus sequitur ventrem); os testamentos e inventários, que dispunham sobre os bens deixados por um indivíduo após sua morte; a imprensa, que deu destaque ao ato de alforria, sobretudo nos anos finais do escravismo; os documentos das estações fiscais de coletorias de rendas, que realizaram as matrículas entre 1871 e 1887. Havia ainda as situações nas quais, segundo Eisenberg, os escravos podiam ser libertos contra a vontade do senhor, como no caso de guerras, ou quando eram enjeitados, ou ainda quando denunciavam os senhores por crimes cometidos. No entanto, para o pesquisador essa é uma documentação que se encontra bastante espalhada em fontes diversas. O autor atentou também para a necessidade de uma pesquisa meticulosa, por meio do cruzamento dessas fontes, objetivando evitar as possíveis repetições registradas nas mesmas. ${ }^{8}$

De acordo com Adauto Damásio, em estudo sobre as alforrias em Campinas na primeira metade do século XIX, as cartas de alforria registradas em cartório não foram as mais utilizadas para libertar os cativos, e sim os testamentos/inventários. Em sua pesquisa o historiador desenvolveu um diálogo constante com o trabalho de Eisenberg, que pesquisou a mesma localidade. Segundo Damásio, as preocupações de Eisenberg com relação

6 EISENBERG, Peter. Homens esquecidos: escravos e trabalhadores livres no Brasil, séculos XVIII e XIX, p.248. "O escravo que, por meio de seu pecúlio, obtiver meios para indenização de seu valor tem direito à alforria. Se a indenização não for fixada por acordo, o será por arbitramento". Lei 2040, art. 4오 § 2o. Colleção das Leis do Império do Brasil de 1871. Rio de Janeiro, 1871, t.XXXI, parte I, p.147-151.

7 EISENBERG, Peter. Homens esquecidos, p.248.

8 EISENBERG, Peter. Homens esquecidos. Sheila de Castro Faria destacou que "a alforria cartorária, a das cartas de alforria, não era a única forma de um escravo ter sua liberdade legalizada. Havia também as alforrias nos testamentos ou codicílos, na pia batismal, essa última quase sempre de crianças, e as cartas, ou papéis particulares, não registradas em cartório. Todos eram meios legais de se obter e provar a liberdade". FARIA, Sheila de Castro. A riqueza dos libertos: os alforriados no Brasil escravista. In: CHAVES, Claudia Maria das Graças e SILVEIRA, Marco Antonio. (orgs.) Território, conflito e identidade. Belo Horizonte/Brasília: Argvmentvm/CAPES, 2007, p.16. 
aos documentos para o estudo das alforrias são inteiramente pertinentes. Junto às cartas de alforria, os testamentos e os registros paroquiais de batismos são fontes importantes, senão essenciais, para o estudo das alforrias no Brasil. ${ }^{9}$

No cruzamento entre as cartas lavradas em cartório e os testamentos, o pesquisador percebeu que o número de alforrias em testamentos que não foram registradas em cartório, entre os anos de 1829-1838, foi de 86, enquanto que Eisenberg encontrou para o mesmo decênio 56 cartas de alforria em cartório. Damásio então concluiu que: "O número de alforriados em Campinas neste decênio foi, portanto, 153,57\% maior do que as apontadas por Eisenberg, somando assim 142 alforrias $(56+86)$. Assim (...) a carta de alforria não foi o instrumento mais utilizado para libertar o cativo, pelo menos em Campinas na primeira metade deste século". ${ }^{10}$

Para Damásio, a explicação para tal diferença residia no fato de que tanto o inventário quanto o testamento eram atos judiciais, portanto, de caráter legal, não sendo preciso qualquer outro documento para o seu reconhecimento. Segundo ele, os escravos que foram alforriados em testamentos/inventários e que registraram suas alforrias em cartório o fizeram muito provavelmente pensando em sua mobilidade geográfica, visto que para tanto necessitavam de suas cartas para apresentar em caso de dúvida quanto a sua nova condição social.

Nos testamentos, observamos uma porcentagem altamente significativa de alforrias incondicionais (63,85\%), o que vimos ser um índice inversamente proporcional aos obtidos por Eisenberg para a primeira metade do século XIX, também em Campinas, nas cartas de alforrias registradas em cartório. ${ }^{11}$

Em síntese, "as alforrias concedidas em testamento mostraram um perfil de alforriados bastante diverso dos descritos nas cartas de alforria registradas em cartório. (...) dado que talvez seja o mais significativo". ${ }^{12}$

Roberto Guedes chegou às mesmas conclusões de Damásio no que concerne às proporções das alforrias em testamentos/inventários e cartas de liberdade. Em seu trabalho sobre a localidade de Porto Feliz (SP) em fins do século XVIII e a primeira metade do século XIX, por meio da análise de variados tipos de fonte, o pesquisador também encontrou mais escravos alforriados em testamento/inventário do que nas cartas registradas em cartório. Além das hipóteses já levantadas por outros autores para explicar essa situação, como a da legalidade reconhecida aos testamentos e outros

9 DAMÁSIO, Adauto. Alforrias e ações de liberdade em Campinas na primeira metade do século XIX. São Paulo: Universidade Estadual de Campinas, 1995. (História, Dissertação de Mestrado).

10 DAMÁSIO, Adauto. Alforrias e ações de liberdade em Campinas na primeira metade do século XIX, p.10.

11 DAMÁSIO, Adauto. Alforrias e ações de liberdade em Campinas na primeira metade do século XIX, p.25.

12 DAMÁSIO, Adauto. Alforrias e ações de liberdade em Campinas na primeira metade do século XIX, p.31. 
documentos, o autor destacou o reconhecimento social como legitimador daquelas alforrias. ${ }^{13}$ De acordo com Ferreira: "Mais importante, pode ser que bastasse declarar perante muita gente: era o reconhecimento social da alforria". ${ }^{14}$ Entre 1806 e 1868, o autor encontrou 130 cartas de alforria que diziam respeito a 147 cativos. Porém, no exame feito nos testamentos, inventários e verbas testamentárias Guedes verificou um total de 495 libertos, $11,6 \%$ da população daquela localidade, que era de 1506 cativos, ou seja, "em quase 90 anos foram libertados 495 escravos, 5,5 ao ano, mais do que o dobro das lançadas em notas". 15

Lizandra Meyer Ferraz estudou as alforrias em Campinas nos períodos de 1836-1845 e 1860-1871. Utilizando-se de quatro fontes principais (testamentos, inventários post mortem, autos de prestação de contas testamentárias e escrituras notariais de carta de alforria) estabeleceu um diálogo constante com os trabalhos de Eisenberg e Damásio sobre a mesma localidade. A historiadora chegou à constatação de que houve um grande número de alforriados nos testamentos/inventários maior que no cartório, corroborando as conclusões de Damásio. ${ }^{16}$

A autora reforçou a necessidade de se proceder a um cruzamento entre alforrias registradas em testamentos, inventários, cartórios e registros paroquiais. Sugestão já levantada por Peter Eisenberg. Fazendo uso deste procedimento metodológico, ela destacou que a população forra do município campineiro foi maior do que a exposta no trabalho de Eisenberg. Ainda de acordo com este trabalho, a procura dos escravos pelo cartório só aumentou na segunda metade do século XIX em virtude de uma maior utilização, por parte da sociedade, de tal comprovante.

Lizandra Ferraz destacou também que houve um maior índice de formalização em cartório entre os alforriados nos inventários do que entre os libertos no testamento. Como explicação para esse padrão, argumentou que o mesmo se deu em virtude de ser o testamento um instrumento público, assim como a prestação de contas testamentária. Existiu, nos dois períodos estudados, um perfil diverso dos alforriados em testamento e no inventário em virtude do caráter filantrópico que estes documentos apresentaram, pois atestavam as últimas vontades de senhores e senhoras escravistas. A autora sugere que:

Para certos grupos de escravos alforriados nos processos de herança, a formalização do registro no cartório era desnecessária enquanto que para outros grupos - possivelmente os menos agraciados com a prática de concessão das

13 GUEDES, Roberto. Egressos do cativeiro: trabalho, família, aliança e mobilidade social (Porto Feliz, São Paulo, c.1798-c.1850). Rio de Janeiro: Mauad X/Faperj, 2008.

14 GUEDES, Roberto. Egressos do cativeiro, p.187. (grifo do original).

15 GUEDES, Roberto. Egressos do cativeiro, p.190.

16 FERRAZ, Lizandra Meyer. Testamentos, alforrias e liberdade: Campinas, século XIX. São Paulo: Universidade Estadual de Campinas, 2006, p.87. (História, Monografia de Conclusão de Curso). 
alforrias - esta formalização era essencial. Da mesma maneira, apontamos que a apresentação dos comprovantes de liberdade nos processos de prestação de verbas testamentárias que reconheciam os escravos como forros, influenciou no registro em cartório, i.e., para a maioria dos libertos cujos comprovantes de liberdade foram apresentados nas verbas testamentárias, a formalização de sua liberdade no cartório não foi realizada. ${ }^{17}$

A pesquisadora constatou ainda que após a extinção do tráfico internacional de escravos houve um aumento das alforrias em Campinas, sobretudo entre os escravos pertencentes a grandes proprietários. Todavia, as taxas eram baixas em comparação com as das pequenas propriedades. Foi no período entre os anos de 1860 e 1871 que ocorreu a maioria das alforrias condicionais. Para Ferraz:

o aumento nesta frequência deve estar ligado a adoção de uma política senhorial de controle tanto da população cativa (através da expectativa de liberdade) quanto da população liberta (através do recurso da gratidão) numa época em que os primeiros sinais do fim da escravidão já estavam sendo soados. ${ }^{18}$

Como já dissemos, Eisenberg problematizou se as cartas de alforria seriam a única fonte para se estudar as manumissões e se não havia outras que pudessem ajudar na compreensão daquele ato. Procuramos seguir as dicas deste historiador no que diz respeito à indicação de outros documentos possíveis para o estudo das alforrias, bem como ao intercruzamento entre fontes variadas. Essa abordagem, já empreendida em outros trabalhos como os de Robert Slenes, Carlos Vogt e Peter Fry; Damásio; Guedes e Lizandra Ferraz, vem se mostrando bastante produtiva para o entendimento das práticas de manumissão no Brasil escravista. ${ }^{19} \mathrm{O}$ cruzamento de diversas fontes possibilita ainda alargar e até mesmo desmistificar algumas hipóteses sobre as práticas de alforria. Um exemplo disto diz respeito às explicações sobre o perfil do alforriado padrão feito a partir de apenas um tipo de documentação, ou às que atribuem estar em um tipo específico de documentação a quase totalidade das alforrias. Todavia, cabe ressaltar que não estamos aqui descartando os trabalhos sobre as alforrias baseados em um tipo de fonte, visto que eles permitem ampliar as análises sobre essa temática. ${ }^{20}$

17 FERRAZ, Lizandra Meyer. Testamentos, alforrias e liberdade, p.87.

18 FERRAZ, Lizandra Meyer. Testamentos, alforrias e liberdade, p.88

19 SLENES, Robert; VOGT, Carlos e FRY, Peter. Cafundó: a África no Brasil, linguagem e sociedade. São Paulo: Companhia das Letras, 1996; DAMÁSIO, Adauto. Alforrias e ações de liberdade em Campinas na primeira metade do século XIX; GUEDES, Roberto. Egressos do cativeiro; FERRAZ, Lizandra Meyer. Testamentos, alforrias e liberdade.

20 Um exemplo disso é o trabalho de: BERTIN, Enidelce. Alforrias na São Paulo do século XIX: liberdade e dominação. São Paulo: FFLCH/USP/Humanitas, 2004. 


\section{Alforrias em grandes propriedades da Zona da Mata Mineira}

Para Eduardo França Paiva, o enorme contingente mancípio mineiro forçou a adaptação de formas que pudessem garantir a sua sustentação e o controle daquela população. ${ }^{21} \mathrm{O}$ autor observou na prática das alforrias uma estratégia eficaz de dominação senhorial, que objetivava incutir àquela população a possibilidade sempre presente de liberdade. Entretanto, esta era uma relação de mão-dupla, pois os cativos também desenvolveram estratégias a partir de experiências das mais variadas, com o intuito de obter suas manumissões. Portanto, a alforria não pode ser simplesmente vista como concessão senhorial, mas também como conquista daqueles indivíduos escravizados.

As alforrias fazem parte dessa estratégia de dominação social, uma vez que representavam, para os submetidos, a oportunidade legal de abandonarem essa condição. Neste sentido, elas tornaram-se eficazes instrumentos de manutenção da ordem, porque, pelo simples fato de existirem virtualmente, acabavam inibindo rebeliões, revoltas e outros movimentos contestatórios, nos planos coletivo e individual. Contudo, as alforrias simultaneamente incentivavam, entre os escravos, o desenvolvimento de estratégias que proporcionassem obtê-las. Por isso, não podem ser vistas apenas como concessões, mas, também como conquistas de uma massa anônima de agentes históricos. ${ }^{22}$

As manumissões na Zona da Mata Mineira foram o objeto de pesquisa de Henrique Duarte Lacerda, que estudou os padrões das alforrias em Juiz de Fora (MG) entre 1844 e 1888, onde levantou 744 registros de manumissões (1.093 cativos). Ainda, "como fontes complementares para qualificar alguns apontamentos" levantou oito registros de contratos de prestação de serviços e quatro testamentos que diziam respeito a escravos que deveriam ser alforriados, bem como alguns inventários post-mortem. Além das variáveis obtidas por meio das análises quantitativas, o pesquisador procurou compreender os motivos da concessão das cartas de liberdade. Outra preocupação de Lacerda foi a de observar se as mesmas eram oriundas de uma estratégia dos senhores em manter sua mão-de-obra naquele município cafeeiro, ou se em contrapartida foram os escravos que

21 Sobre as alforrias em Minas Gerais, conferir entre outros: HIGGINS, Kathleen J. The slave society in Eighteenthcentury Sabará: a community study in colonial Brazil. New Haven: Yale University, 1987; LIBBY, Douglas Cole e PAIVA, Clotilde Andrade. Alforrias e forros em uma freguesia mineira: São José d'El Rey em 1795. Revista Brasileira de Estudos da População, v.17, n.1/2, jan/dez, 2000; GONÇALVES, Andréa Lisly. As margens da liberdade: prática de alforrias em Minas Gerais colonial e imperial. São Paulo: Universidade de São Paulo, 2000. (História, Tese de Doutorado); GONÇALVES, Andréa Lisly. Alforrias na Comarca de Ouro Preto (1808-1870). População e Família. São Paulo: CEDHAL/FFLCH/USP/Humanitas, 2000; LIBBY, Douglas e GRAÇA FILHO, A. A. Reconstruindo a liberdade - Alforrias e forros na freguesia de São José do rio das Mortes, 1750-1850. Varia Historia, Belo Horinzonte, v.30, p.112-151, 2003; GRAÇA FILHO, A. A. e LIBBY, Douglas. Notarized and baptismal manumissions in the parish of São José do Rio das Mortes, Minas Gerais (c. 1750-1850). The Americas, v.66, p.211-240, 2009.

22 PAIVA, Eduardo França. Escravos e libertos nas Minas Gerais do século XVIII: estratégias de resistência através dos testamentos. São Paulo: Annablume, 1995, p.101. 
utilizaram estratagemas para obter suas manumissões no momento de maior ascensão da cultura cafeeira daquele município, "portanto, em uma conjuntura desfavorável à concessão das mesmas". ${ }^{23}$

Baseando-se na historiografia que apontou a década de oitenta do século XIX como sendo o momento no qual ocorreram mais alforrias coletivas, em virtude das campanhas abolicionistas, Lacerda dividiu o seu recorte cronológico em dois momentos (Tabela I). O primeiro entre 1844 e 1880, período que abarcou 56,71\% das manumissões, e o segundo entre 1881 e 1888, com 43,49\% de alforrias. As cartas de liberdade foram classificadas como gratuitas e onerosas condicionais (cartas de liberdade coartadas, compradas, prestação de serviços); incondicionais (sem nenhum tipo de condição explicita); parciais (aquela em que o proprietário libertou a(s) parte(s) que possuía sobre um cativo de maneira condicional ou não) e verba testamentária. As duas primeiras somadas abarcaram a maioria das alforrias, num total de 991 (90,6\%), sendo que as gratuitas e onerosas condicionais tiveram uma porcentagem de 57,01\% e as incondicionais 42,99\%. ${ }^{24}$ De acordo com Lacerda:

Notamos que entre 1844 e 1860 as cartas Onerosas e Gratuitas Condicionais e as Incondicionais possuíram, praticamente a mesma proporção. Na década final do escravismo, as alforrias incondicionais mantiveram uma porcentagem proporcional às décadas anteriores, enquanto que as alforrias Onerosas e Gratuitas condicionais aumentaram significativamente. ${ }^{25}$

Tabela I

Tipologia das Alforrias em Juiz de Fora (MG) - 1844-88

\begin{tabular}{cccccc}
\hline Década/Tipo & $\begin{array}{c}\text { Onerosa e Gratuita } \\
\text { Condicional }\end{array}$ & Incondicional & Parcial & $\begin{array}{c}\text { Verba } \\
\text { Testamentária }\end{array}$ & $\begin{array}{c}\text { Total por } \\
\text { Década }\end{array}$ \\
\hline $1844-50$ & 15 & 03 & - & 02 & 20 \\
$1851-60$ & 61 & 56 & - & 16 & 133 \\
$1861-70$ & 74 & 99 & 4 & 10 & 187 \\
$1871-80$ & 122 & 130 & 13 & 12 & 277 \\
Total Parcial & 272 & 288 & 17 & 40 & 617 \\
$1881-88$ & 293 & 138 & 30 & 15 & 476 \\
Total Geral & 565 & 426 & 47 & 55 & 1093 \\
\hline
\end{tabular}

Fonte: Apud: LACERDA, Antonio Henrique Duarte. Os padrões das alforrias em um município cafeeiro em expansão: Juiz de Fora, zona da mata de Minas Gerais, 1844-88. São Paulo: Fapeb/Annablume, 2006, p.63.

23 LACERDA, Antonio Henrique Duarte. Os padrões das alforrias em um município cafeeiro em expansão: Juiz de Fora, zona da mata de Minas Gerais, 1844-88. São Paulo: Fapeb/Annablume, 2006, p.16.

24 LACERDA, Antonio Henrique Duarte. Os padrões das alforrias em um município cafeeiro em expansão.

25 LACERDA, Antonio Henrique Duarte. Os padrões das alforrias em um município cafeeiro em expansão, p.65. 
No que diz respeito às cartas de alforria compradas em Juiz de Fora, o pesquisador conseguiu encontrar dez compras feitas por famílias, envolvendo nestes casos diversas relações familiares. Segundo o autor:

As cartas compradas por familiares do alforriado somaram dez registros. Em quatro delas os maridos compraram as alforrias de suas esposas; em duas, os filhos compraram a alforria das mães; em uma, a mãe comprou a alforria da filha; em uma, a irmã comprou a alforria do irmão; em uma, um pai comprou a alforria de sua filha; em uma o noivo (livre) comprou a alforria de sua noiva. ${ }^{26}$

Outras constatações foram feitas por ele, dentre elas, a de que no município de Juiz de Fora houve uma percentagem de 68,8\% (44 cartas) de cartas de alforria que mencionaram o afeto como motivo para a manumissão de forma gratuita e sem restrições aparentes. Ainda de acordo com Lacerda, naquele município o número de alforrias parece não ter sido ditado pelo fator econômico, pelo menos não como queria Gorender, que argumentou serem elas mais frequentes nos momentos de depressão econômica. Em Juiz de Fora, foi no período de maior expansão do café entre 1850 e 1870 , no qual a localidade se caracterizou como uma das maiores produtoras daquele grão, que a evolução das manumissões continuou a crescer. ${ }^{27}$

Tabela II

"Ato legal” das Alforrias distribuídas entre os cativos das famílias Paula Lima, Barbosa Lage e Dias Tostes, século XIX

\begin{tabular}{ccccccc}
\hline $\begin{array}{c}\text { Famílias senhoriais } \\
\text { "Categoria legal"de alforria }\end{array}$ & $\begin{array}{c}\text { Paula } \\
\text { Lima }\end{array}$ & $\%$ & $\begin{array}{c}\text { Dias } \\
\text { Tostes }\end{array}$ & $\%$ & $\begin{array}{c}\text { Barbosa } \\
\text { Lage }\end{array}$ & $\%$ \\
\hline Testamento & 22 & 50,0 & 20 & 51,3 & 04 & 25,0 \\
Inventário & 15 & 34,1 & 06 & 15,4 & 08 & 50,0 \\
Cartas & 05 & 11,3 & 13 & 33,3 & 04 & 25,0 \\
Pia batismal & 01 & 2,3 & - & - & - & - \\
Fundo de emancipação & 01 & 2,3 & - & - & - & - \\
Total & 44 & 100 & 39 & 100 & 16 & 100 \\
\hline
\end{tabular}

Fonte: Inventários post-mortem do Arquivo Histórico da Universidade Federal de Juiz de Fora (AHUFJF). Livros de Notas e Escrituras Públicas do Arquivo Histórico da Cidade de Juiz de Fora (AHCJF). Registros paroquiais do Arquivo da Catedral Metropolitana de Juiz de Fora (ACMJF) e Cúria Metropolitana - Arquivo da Arquidiocese de Juiz de Fora (CM - AAJF).

A partir de agora vamos adentrar no mundo daquelas três famílias e também no dos escravos, para conhecer um pouco mais sobre como se deu o trânsito entre a escravidão e a liberdade naquelas propriedades. Nosso método foi o de cruzamento de fontes relativas às escravarias dos

26 LACERDA, Antonio Henrique Duarte. Os padrões das alforrias em um município cafeeiro em expansão, p.71.

27 LACERDA, Antonio Henrique Duarte. Os padrões das alforrias em um município cafeeiro em expansão. 
Dias Tostes, Paula Lima e Barbosa Lage, com o intuito de conhecer um pouco mais sobre a política das alforrias que se deram entre os senhores e seus escravos e que foram fundamentais para estes indivíduos. Nossas fontes principais são os inventários, os testamentos, as alforrias em cartório, as alforrias na pia batismal e as prestações de contas testamentárias. A Tabela II demonstra o "Ato legal" das alforrias (tipo de documento no qual as mesmas foram anotadas) e o número de liberdades distribuídas nas três famílias, pelo menos as manumissões que pudemos conhecer.

Primeiramente, se percebe que aqueles que mais alforriaram seus cativos foram os Paula Lima, seguidos pelos Dias Tostes e por último, com um número bastante inferior às outras duas famílias, os Barbosa Lage.

Com relação as 44 alforrias distribuídas pelos Paula Lima, podemos perceber que a metade delas se deu por meio dos testamentos de última vontade - 22 (50,0\%). Seguidas pelas alforrias nos inventários 15 (34,1\%); logo após encontramos 05 cartas de alforria (11,3\%). Por último, as alforrias na pia batismal e pelo fundo de emancipação, cada uma com 01 manumissão $(2,3 \%)$. Cabe ressaltar que estas duas últimas modalidades de alforria foram exclusividade dos Paula Lima. Portanto, nota-se que a maior parte das alforrias não ocorreu por meio das cartas. Isto reforça as argumentações de Eisenberg sobre a necessidade de um intercruzamento de fontes para que se possa ter acesso a um número mais próximo da realidade. Da mesma maneira, corrobora os estudos feitos por outros pesquisadores já citados, de que as alforrias em cartório não constituíram a forma mais comum de manumissão.

Os Paula Lima libertaram mais em testamentos, inventários e cartas; enquanto que os Dias Tostes manumitiram mais em testamentos, seguidos de cartas e, por último, em inventários. No total foram 20 as alforrias testamentárias "distribuídas" por esta família, que representavam mais da metade das manumissões (51,3\%). A segunda maior percentagem de manumitidos por eles obteve sua liberdade por meio das cartas de liberdade, 13 (33,3\%), e em último lugar vinham as manumissões em inventário 06 $(15,4 \%)$. As alforrias distribuídas por essas famílias, portanto, ressaltam a importância das liberdades testamentárias como forma bastante comum no ato de alforriar.

Os Barbosa Lage foram os que menos alforriaram. Conseguimos localizar somente 16 cativos alforriados por esses senhores. A maioria das liberdades estava nos inventários, 08 (50\%), sendo todos escravos quartados pelo Dr. Francisco de Assis Barbosa Lage. As outras oito dividiram-se igualmente entre liberdades em testamento e em cartas de alforria, cada uma perfazendo $25 \%$ do total de alforrias. Esses dados reforçam o já exposto e demonstrado pela análise das outras duas famílias senhorias, ou seja, apesar de toda a importância da manumissão registrada em cartório, ela não foi condição sine qua non para a liberdade. Outros documentos 
tiveram o mesmo peso legal, tanto para os senhores quanto para os escravos. Além da legalidade de tais ritos jurídicos, o conhecimento público daquelas manumissões dadas a conhecer nos inventários, testamentos, pia batismal, bastavam para a confirmação do status de libertos àqueles excativos. O registro em cartório deve ter sido feito muito mais pelos libertos, que pensavam na mobilidade geográfica, e por aqueles que tinham dúvidas quanto ao respeito dos herdeiros/legatários com relação às disposições de última vontade expressas por algum parente, por exemplo, nos testamentos.

Em síntese, a análise das manumissões "concedidas" pelos Dias Tostes, Paula Lima e Barbosa Lage demonstram como os caminhos para a alforria eram muitos e também tortuosos. Para a obtenção de sua liberdade, os cativos tiveram de encontrar brechas dentro do sistema escravista, sempre com muita astúcia e por meio de estratégias diversas. A justiça também foi utilizada com o intuito de preservar a promessa da liberdade e as vontades dos senhores, mesmo as não expressas em documento tiveram de ser levadas em conta. Na maioria das vezes as liberdades apareceram nas fontes como concessões senhorias, fruto da justiça, dos sentimentos de solidariedade dos senhores para com seus cativos, da fé cristã. Todavia, marcados por essa doação, esse favor sempre embasado nos "bons serviços" prestados pelos escravizados, escondiam-se situações muito mais complexas.

Nem sempre essas histórias ocorreram dessa maneira e é importante ressaltar que as trajetórias de cada escravo, de cada manumissão, foram muito mais complexas que o resultado impresso no testamento senhorial. Muito além dos bons serviços prestados, os alforriados (...) certamente investiram em habilidades, em informações, em comportamento, em práticas cotidianas, em sentimentos, para tempos mais tarde, serem eles os escolhidos pelo proprietário moribundo, entre todos os outros companheiros, para então, "ganharem" suas cartas de liberdade. ${ }^{28}$

As famílias consanguíneas e estendidas, bem como a herança africana, foram de vital importância para a vida dos cativos, tanto na escravidão quanto na liberdade. Nos dizeres de Maria Inês Côrtes de Oliveira:

A transmissão da tradição africana quer ao nível da família parcial ou nuclear, quer da sutil rede de relações da 'família por afinidade' constituíram algumas das múltiplas formas pelas quais, no quotidiano, os africanos [e crioulos] libertos conseguiram preservar os elementos culturais de que dispunham para enfrentar a conquista de novos espaços. ${ }^{29}$

28 PAIVA, Eduardo França. Escravidão e universo cultural na colônia: Minas Gerais, 1716-1789. Belo Horizonte: Editora da UFMG, 2001, p.167.

29 OLIVEIRA, Maria Inês Côrtes de. O liberto: o seu mundo e os outros. São Paulo: Corrupio; [Brasília, DF]: CNPq, 1988, p.73. 
Acreditamos que o caso emblemático de Bernardina e sua família, que obtiveram além da liberdade legados dados por sua senhora Inácia Werneck, possa ser de utilidade para o entendimento da importância da alforria para as famílias cativas.

\begin{abstract}
A situação desta família era, na verdade, ambígua; como muitos outros, eles ocupavam uma posição incerta entre cativos e livres. Depois de 1871 e da aprovação da lei Rio Branco, ou do Ventre Livre, como era chamada popularmente, a liberdade condicional podia ser imposta por no máximo sete anos. Mas, na época [quando?] de Inácia e Bernardina, práticas costumeiras, costuradas numa rede de obrigações desigualmente recíprocas, regulavam a concessão da liberdade. Em algum momento do passado, Inácia dera a Bernardina sua carta de alforria, porém com uma condição: que continuasse a servir à dona enquanto ela vivesse, muito mais do que sete anos, como acabou acontecendo. Com a liberdade incompleta, Bernardina continuou escrava até a morte de Inácia, mas ao mesmo tempo, na condição de mulher provisoriamente livre, podia contar, com uma espécie de contrato, com alguma força. Conforme o costume, Inácia não poderia vendê-la sem passar para o novo dono o compromisso de libertála, nem a promessa de liberdade, uma vez feita, poderia ser descumprida, o que servia tanto de proteção contra a escravização de pessoas libertas, quanto como um modo de cumprir uma promessa feita a um escravo. Com sua liberdade reconhecida após a morte de Inácia, Bernardina tornou-se uma mulher plenamente livre. ${ }^{30}$
\end{abstract}

Na luta pela liberdade, as famílias escravas constituíram papel fundamental. A liberdade para os cativos ancorava-se na perspectiva de uma vida melhor para eles e seus familiares em sua nova condição jurídica; projeto no qual muitos participaram. Para tanto, os escravos não se furtaram a cada vez mais lutar para retirar da escravidão suas mães, pais, filhos, avós, primos, ... Aqueles com quem iriam reconstruir suas vidas no mundo da liberdade.

\title{
Senhores de muitos escravos e poucas alforrias
}

Recentemente, os estudos sobre o tamanho das posses e a quantidade de alforrias praticadas pelos senhores têm demonstrado uma tendência a uma correlação inversa entre tamanho da propriedade e a proporção de alforriados. Ou seja, quanto maior o número de cativos de uma propriedade menores as percentagens de alforria.

Em Santiago de Cuba (1780-1803), José Luis Belmonte Postigo sugeriu, no que concerne ao tamanho das posses, que os pequenos proprietários procuraram dificultar a liberdade de seus cativos, pois estes eram sua única

30 GRAHAM, Sandra Lauderdale. Caetana diz não: histórias de mulheres da sociedade escravista brasileira. São Paulo: Companhia das Letras, 2005, p.145-147 
fonte de rendas, e o faziam dando mais alforrias condicionais do que os grandes proprietários. ${ }^{31}$

Segundo Robert Slenes, baseando-se em seis análises sobre as alforrias testamentárias em Minas Gerais, Rio de Janeiro e São Paulo, entre os séculos XVIII e XIX, as manumissões de acordo com os tamanhos das propriedades sugerem largos contrastes. Segundo os seus cálculos, os pequenos proprietários de cativos (1-20 cativos) alforriaram proporcionalmente cerca de 2,9 a 17,8 vezes mais escravos do que os grandes (+ de 40 cativos ou + de 20 para um dos estudos). ${ }^{32}$

More importantly, three analyses, which calculate the proportion of bondspeople freed by wills in all probate records of slave owners, dying either testate or intestate, demonstrate that small masters (with 1-20 slaves) manumitted slaves from 2.3 to 10.2 times the rate of large proprietors (with over 40 bondspeople). In these latter cases, the proportions freed were, respectively, 9.1 percent (small holders) versus 3.9 percent (large owners) in the Comarca (District) of Rio das Mortes (southern Minas Gerais) from 1716-1789; 9.2 against 0.9 percent in Campinas, São Paulo from 1836 to 1845; and 16.7 versus 3.4 percent in Campinas during 1860 to 1871.33

No já citado estudo de Paiva, sobre a Comarca do Rio das Velhas e Rio das Mortes, o historiador percebeu que nas duas regiões os pequenos proprietários alforriaram um maior número de cativos. Nas duas comarcas conjuntamente, os senhores de 1 a 5 cativos alforriaram 29,4\%; os de 6 a $10,23,5 \%$; os de 11 a 20 , libertaram 15,0\%; enquanto que os possuidores de 21 a 40 escravos, e os com mais de 41 , alforriaram, respectivamente $7,4 \%$ e $2,8 \%$.

Quanto mais cativos um senhor possuía, menos ele os alforriava e/ou coartava. (...) Voltando a regra, os menores proprietários é quem mais alforriavam e/ou coartavam mancípios. Isso significa que nas pequenas posses, o tipo mais característico das regiões urbanizadas, os acordos se fizeram proporcionalmente mais intensos, dada, claro, a proximidade cotidiana das relações senhor/escravo.

31 POSTIGO, José Luis Belmonte. Com la plata ganada y su próprio esfuerzo. Los mecanismos de manumisión em Santiago de Cuba, 1780-1803. Revisto Del Grupo de Estúdios Afroamericanos, Universidad de Barcelona. EAVirtual, n.3, 2005.

32 As seis análises referidas pelo autor são as referentes aos estudos de PAIVA, Eduardo França. Escravidão e universo cultural na colônia; SOARES, Márcio de Sousa. A remissão do cativeiro: alforrias e liberdades nos Campos dos Goitacases, c.1750 - c.1830. Niterói, RJ: Universidade Federal Fluminense, 2006. (História, Tese de Doutorado); GUEDES, Roberto. Egressos do cativeiro; FERRAZ, Lizandra Meyer. Testamentos, alforrias e liberdade. No caso da pesquisa empreendida por Lizandra, incluem-se também as alforrias no decorrer do inventário.

33 "Mais importante, três análises, que calcularam as proporções de libertos por testamentos em todos os registros de proprietários de escravos em testamento ou não, demonstram que pequenos senhores (com 1-20 escravos) manumitiram proporcionalmente entre 2.3 a 10.2 vezes mais escravos do que grandes proprietários (acima de 40 cativos). Nestes últimos casos, a proporção de libertos foi, respectivamente, 9.1 por cento (pequenos possuidores) versus 3.9 por cento (grandes proprietários) na Comarca do Rio das Mortes (sul de Minas Gerais) entre 1716 - 1789; 9.2 contra 0.9 por cento em Campinas, São Paulo, entre 1836 e 1845; e 16.7 versus 3.4 por cento em Campinas durante 1860 e 1871." SLENES, Robert. A "Great Arch" descending: Reflections on manumission rates, slave identities and black social mobility in southeastern Brazil, 1791-1888. Campinas, novembro de 2008. (Texto apresentado para discussão nas linhas de pesquisa em História Social da Cultura e História Social do Trabalho - CECULT/Unicamp). 
Com a mesma importância, outros atores contribuíram para o estabelecimento desses arranjos. Entre eles, a ascendência escrava ou liberta de significativa parcela desses senhores mais modestos, o trabalho conjunto, no dia-a-dia, de donos de propriedades e a acentuada e mútua dependência. (...) As cartas de liberdade e de corte eram (...), essencialmente urbanas, embora não fossem completamente desconsiderados em áreas rurais. Mas foi preferencialmente pelas ruas, becos e largos que andou a maioria dos homens e mulheres forros e coartados. ${ }^{34}$

Na cidade do Rio de Janeiro do século XIX, onde as manumissões raramente eram gratuitas, as cartas de alforria demonstram que "o típico senhor que alforriava escravos não era o grande fazendeiro ou portador de título de nobreza, mas um homem de posição social média de profissão urbana". ${ }^{35}$ De acordo com Mary Karasch:

Embora os dados sobre ocupação estejam incompletos, eram poucos os da elite rural que libertavam escravos. Em outras palavras, os cativos que pertenciam a modestos donos urbanos tinham maior probabilidade de ganhar alforria do que os escravos de fazendeiros. (...) Dos 167 senhores rurais livres que alforriaram escravos, somente sete eram fazendeiros. Essa amostra sugere que a elite fundiária não era significativa na alforria e que os escravos cariocas mandados para o campo, em especial depois de 1850, perdiam a esperança de liberdade. (...) Em outras palavras, os escravos tinham maior probabilidade de obter a liberdade se pertencessem a homens ou mulheres urbanos de renda média, e menor chance, se fossem dos homens da elite rural dominante. ${ }^{36}$

Ricardo Salles, referindo-se às alforrias dadas durante o processo de inventário, não incluindo em sua análise as manumissões em testamentos, averiguou que em áreas rurais da província fluminense, as plantations "maduras tendiam a alforriar menos. E no interior dessas áreas, a alforria era mais rara nos plantéis das plantations do que nas médias e pequenas propriedades ou posses de escravos". ${ }^{37}$

Analisando as alforrias entre 1839 e 1880, Salles concluiu que, tomadas em conjunto, das alforrias em Vassouras (RJ), registradas em inventários, $60,66 \%$ delas foram doadas pelos micros (01 e 04 cativos), pequenos (5 a 19 cativos) e médios proprietários (20-49 cativos). Enquanto que os mega (mais de 100 cativos) e grandes proprietários (50 até 99 escravos) foram responsáveis por 39,34\%. Entretanto, o pesquisador verificou que a partir de 1836/1850 os mega e grandes possuidores de cativos nunca possuíram menos do que $70 \%$ dos alforriados em inventários. "Fato que mostra

34 PAIVA, Eduardo França. Escravidão e universo cultural na colônia, p.173-178.

35 KARASCH, Mary C. A vida dos escravos no Rio de Janeiro (1808-1850). São Paulo: Companhia das Letras, 2000, p.440.

36 KARASCH, Mary C. A vida dos escravos no Rio de Janeiro (1808-1850), p.449-451.

37 SALLES, Ricardo. E o Vale era o escravo. Vassouras, século XIX. Senhores e escravos no coração do Império. Rio de Janeiro: Civilização Brasileira, 2008 
claramente que a prática das alforrias era mais incomum entre grandes megaplantéis". ${ }^{38}$ Segundo esta pesquisa, que chegou a constatações semelhantes às de Karasch:

A baixa taxa de alforrias (...) indica ainda que a concentração espacial e social do cativeiro, no novo quadro demográfico [resultado da estabilização ou mesmo do crescimento da população com base sem sua reprodução vegetativa e no comércio interno de cativos] que passou a dominar as relações entre senhores e escravos, a partir de meados de 1860, re-significou o sentido do instituto da alforria. Senhores, principalmente aqueles que dispunham de grandes plantéis e tinham outros meios de controle sobre eles, tornaram-se cada vez mais relutantes em se desfazer de seus escravos concedendo-Ihes alforria. Quando esta era obtida, era resultado de esforços muito maiores por parte dos cativos do que aqueles que eles tinham despendido antes de 1850. Por outro lado, as novas condições sociais incidiam também no estreitamento do espaço de manobras daqueles poucos que, a duras penas, haviam obtido sua liberdade. De uma prática dominantemente vista como concessão senhorial, a alforria tornou-se mais e mais conquista cativa. ${ }^{39}$

Roberto Guedes, em estudo sobre a localidade de Porto Feliz (SP), c.1798 - c.1850, encontrou entre os testamentos que pesquisou 272 senhores escravistas, sendo que 144 deles (53\%) libertaram escravos naquele ato de última vontade. Os pequenos, médios e grandes testamenteiros libertantes alforriaram, respectivamente, 30,4\%, 15,6\% e 6,4\% dos seus escravos. O autor percebeu então que:

Ao testarem, mais da metade de pequenos, médios e grandes escravistas praticaram o ato da alforria, com uma intensidade um pouco maior entre os grandes senhores, mas sem variações percentuais significativas. Dessa maneira, o ato de alforriar não se relaciona ao tamanho da propriedade. Por outro lado, entre os libertadores, os pequenos senhores, proporcionalmente, foram os que mais contribuíram para o primeiro passo de mobilidade social, alforriando $30,4 \%$ dos seus escravos, representando $34,2 \%$ do total, o que supera os de senhores de média escravaria. Por sua vez, os grandes proprietários só alforriaram $6,4 \%$ de seus cativos, mas os seus libertos formavam a maioria dos alforriados. ${ }^{40}$

Embora não realize, sobre essa questão, uma análise de maneira direta, o estudo de Cristiano Lima da Silva, acerca das alforrias na pia batismal em São João Del Rei entre os anos de 1750-1850, demonstrou que esta modalidade de alforria também beneficiava proporcionalmente mais aos cativos pertencentes a pequenos proprietários do que aos que faziam parte

38 SALLES, Ricardo. E o Vale era o escravo. Vassouras, século XIX, p.291.

39 SALLES, Ricardo. E o Vale era o escravo. Vassouras, século XIX, p.256.

40 GUEDES, Roberto. Egressos do cativeiro, p.192. 
das grandes posses. ${ }^{41}$ Foram 63 os escravistas que alforriaram crianças na pia, cujos inventários post-mortem foram localizados. Somando-se todas as propriedades que tinham entre 1-19 escravos na hora da morte do senhor, os alforriados na pia equivaliam a 30,5\% do total de cativos. Já, nas posses com 20 cativos ou mais, esses libertandos correspondiam a 3,4\% do total inventariado. Refinando ainda mais essas cifras, podemos conhecer mais de perto as percentagens de crianças alforriadas de acordo com o tamanho da posse. Os proprietários que possuíam entre 1 e 4 cativos na hora da morte haviam alforriado 24 (equivalente a 55,8\% dos escravos inventariados); os com 5-9 libertaram 23 (27,4\% dos inventariados) e os com posses em escravos entre 10-19 deram liberdade a 4 (10,0\%). Já os proprietários com 20 a 39 e com mais de 40 escravos alforriaram oito e sete cativos, o que equivalia, respectivamente, a 3,9 e 2,9\%. ${ }^{42}$

Marcio Soares, em pesquisa sobre Campos (RJ), século XVIII e primeira metade do XIX, chegou a conclusões semelhantes. Visualizando as alforrias em testamento (dadas por testadores libertantes), o pesquisador constatou que, proporcionalmente, quanto maiores eram as fortunas dos testadores, menores as chances de alforrias. Também chamou a atenção ao fato de que as proporções entre alforriados pertencentes a testadores sem herdeiros eram sempre maiores do que as entre aqueles que pertenciam a testadores com herdeiros. A maior ou menor presença dos herdeiros era fundamental para a liberdade dos cativos. Nos dizeres do pesquisador:

\begin{abstract}
Certamente que a quantidade de escravos alforriados num testamento estava relacionada com o montante da fortuna daqueles senhores e senhoras. Todavia, isso não significa dizer que as pessoas mais abastadas alforriassem mais. Consegui localizar 79 inventários daqueles testadores que determinaram a alforria de escravos como disposição de última vontade e o exame dessa documentação demonstrou exatamente o contrário. Proporcionalmente os mais ricos e poderosos praticavam menos a alforria e geralmente, quando o faziam, libertavam poucos escravos. Quanto maiores as escravarias, maiores eram as quantidades de homens africanos adultos. Maiores escravarias, maior o distanciamento senhorial com relação a uma parcela dos cativos. Conseqüentemente, menores eram as chances de alforria para os africanos. ${ }^{43}$
\end{abstract}

Embora não tenhamos tantos dados referentes às pequenas posses, assim como os estudos mencionados, podemos estabelecer uma análise a respeito da correlação entre o tamanho da propriedade e a proporção de

41 SILVA, Cristiano Lima da. Como se livre nascera: a alforria na pia batismal em São João Del Rei (1750-1850). Niterói, RJ: Universidade Federal Fluminense, 2004. (História, Dissertação de Mestrado).

42 Como já dissemos, o autor não fala sobre esses dados no texto de sua dissertação. A análise de tais dados foi feita baseada em: SILVA, Cristiano Lima da. Como se livre nascera, Anexo 2, p.151, onde ele cruzou dados sobre escravos inventariados e número de crianças alforriadas e foi feita pelo Professor Robert Slenes a quem agradecemos por ter cedido suas análises.

43 SOARES, Márcio de Sousa. A remissão do cativeiro, p.134-135. 
escravos alforriados. Principalmente porque temos seis casos de grandes proprietários (cinco deles possuidores de inventários com testamento), um número não exíguo, que nos possibilitou rastrear todas as formas de alforrias. Desta forma, vamos nos ater aqui àqueles para os quais houve essa possibilidade, em primeiro lugar com os que alforriaram em testamento, depois com todo o grupo de inventariados, sejam testadores libertantes ou não. A Tabela III apresenta os dados para todas as pessoas das três famílias para as quais foram encontrados inventários post-mortem.

\section{Tabela III}

Inventariados com ou sem testamento e o número de escravos alforriados em testamento: famílias Barbosa Lage, Dias Tostes e Paula Lima, século XIX

\begin{tabular}{|c|c|c|c|c|c|}
\hline Senhores & $\begin{array}{c}\text { Ano do } \\
\text { inventário* }\end{array}$ & $\begin{array}{c}\text { Número } \\
\text { de cativos } \\
\text { inventariados }\end{array}$ & $\begin{array}{c}\text { Com } \\
\text { testamento? }\end{array}$ & $\begin{array}{l}\text { Alforriou em } \\
\text { testamento? }\end{array}$ & $\begin{array}{l}\text { Número de cativos } \\
\text { alforriados/coarta- } \\
\text { dos em testamento }\end{array}$ \\
\hline Manoel Ignacio Barbosa Lage & 1868 & 118 & Sim & $\operatorname{Sim}$ & 01 \\
\hline Antonio Augusto Barbosa Lage & 1868 & 41 & Sim & $\operatorname{Sim}$ & 01 \\
\hline Dr. Francisco de Assis Barbosa Lage & 1880 & 10 & $\operatorname{Sim}$ & $\operatorname{Sim}$ & 08 \\
\hline $\begin{array}{l}\text { D. Florisbella Francisca de Assis } \\
\text { Barbosa Lage Moretzsohn }\end{array}$ & 1882 & 103 & $\operatorname{Sim}$ & Não & - \\
\hline D. Florisbella Augusta Barbosa Lage & 1887 & 10 & Sim & Não & - \\
\hline D. Marianna Cândida de Assis Barbosa & 1881 & 35 & $\operatorname{Sim}$ & Não & - \\
\hline Antonio Dias Tostes* & 1852 & 44 & $\operatorname{Sim}$ & $\operatorname{Sim}$ & 02 \\
\hline Cezario Dias Tostes & 1879 & 04 & $\operatorname{Sim}$ & Sim & 02 \\
\hline Dona Cândida Maria Carlota & 1867 & 56 & Não & - & - \\
\hline Felix Gonçalves da Costa & 1807 & 21 & $\operatorname{Sim}$ & Não & - \\
\hline D. Felicidade Umbelina de Barbosa & 1843 & 17 & Não & - & - \\
\hline Manoel Dias Tostes & 1866 & 29 & Não & - & - \\
\hline Mariano Dutra de Moraes & 1852 & 101 & Não & - & - \\
\hline Custodio Dias Tostes & 1847 & 33 & Não & - & - \\
\hline Comendador Francisco de Paula Lima & 1866 & 204 & $\operatorname{Sim}$ & Sim & 13 \\
\hline $\begin{array}{l}\text { Dona Francisca Benedicta de Miranda } \\
\text { Lima }\end{array}$ & 1877 & 130 & Não & - & - \\
\hline Capitão José Rodrigues de Lima & 1833 & 53 & $\operatorname{Sim}$ & $\operatorname{Sim}$ & 02 \\
\hline Visconde de Uberaba & 1856 & 52 & Não & - & - \\
\hline Dona Maria Antonia de Oliveira & 1856 & 34 & Não & - & - \\
\hline
\end{tabular}

Fonte: Inventários post-mortem do AHUFJF e do Arquivo Público Municipal Professor Altair José Savassi, Barbacena (APMPAJS). * Na verdade temos a prestação de contas de testamentária de Antonio Dias Tostes que, diferentemente de todas as outras fontes deste tipo, traz o número de cativos possuídos por aquele senhor, permitindo então analisar a relação entre o número de cativos possuídos por aquele senhor e a proporção de alforriados naquela faixa de tamanho da posse. 
As alforrias nos inventários com testamento demonstram que mais da metade dos pequenos e grandes senhores alforriaram na hora da morte, sendo que em números absolutos os maiores possuidores de cativos deram mais alforrias que os pequenos. Porém, olhando primeiro para os casos de testadores libertantes (Tabela IV) vemos que, proporcionalmente, os pequenos possuidores de cativos foram os que mais libertaram, $71,4 \%$ do total dos seus cativos. Já os maiores testadores libertantes alforriaram apenas $4,0 \%$ de todos os escravos pertencentes àquelas posses.

\section{Tabela IV \\ Alforrias na morte do senhor em inventários com testadores libertantes, Dias Tostes, Barbosa Lage e Paula Lima, século XIX}

\begin{tabular}{ccccccc}
\hline $\begin{array}{c}\text { Tamanho das } \\
\text { posses }\end{array}$ & $\begin{array}{c}\text { Testadores } \\
\text { libertantes }\end{array}$ & $\begin{array}{c}\text { \% do total de } \\
\text { libertantes }\end{array}$ & $\begin{array}{c}\text { Total de } \\
\text { escravos } \\
\text { possuídos }\end{array}$ & $\begin{array}{c}\text { Número de } \\
\text { Alforrias em } \\
\text { testamento }\end{array}$ & $\begin{array}{c}\text { \% no total de } \\
\text { alforriados }\end{array}$ & $\begin{array}{c}\text { \% alforriados } \\
\text { na faixa de } \\
\text { posse }\end{array}$ \\
\hline $\begin{array}{c}\text { Pequena } \\
(1-20 \text { cativos })\end{array}$ & 02 & 28,6 & 14 & 10 & 34,5 & 71,4 \\
Média & 00 & 0,0 & 00 & 00 & 0,0 & 0,0 \\
$\begin{array}{c}\text { (21-40 cativos }) \\
\text { Grande (41 +) }\end{array}$ & 05 & 71,4 & 460 & 19 & 65,5 & 4,0 \\
Total & 07 & 100 & 474 & 29 & 100 & 6,1 \\
\hline
\end{tabular}

Fonte: Inventários post-mortem do AHUFJF e do APMPAJS (Barbacena).

Os dados para Juiz de Fora, baseados no estudo daquelas três famílias, coadunam-se, guardadas as devidas proporções, com as constatações expostas por outros estudos sobre as alforrias em diversos recortes cronológicos e abarcando várias localidades do sudeste escravista. Todos esses estudos demonstram que as alforrias por testadores libertantes ocorreram com mais frequência nas pequenas posses (Tabela $\mathbf{V}$ ).

Eduardo França Paiva discriminou as faixas de tamanho das propriedades, o que permitiu que refizéssemos as percentagens, de maneira a poder comparar com Juiz de Fora. As faixas de tamanho das posses feitas por Lizandra Ferraz são as seguintes: pequena = 01 a 20 cativos; médias $=21$ a 50 cativos e grandes $=$ mais de 50 . Em seu estudo a pesquisadora, assim como Paiva, distribuiu suas faixas de posse, o que possibilitou o mesmo procedimento feito com os dados de Paiva; permitindo a comparação entre os dados da Comarca do Rio das Velhas e Juiz de Fora. Na pesquisa de Roberto Guedes, as propriedades se distribuem da seguinte maneira: pequenas posses com até 10 escravos, as médias entre 11 e 20 cativos e as grandes mais de 20 escravos. Contudo, não nos foi possível, assim como os dois outros trabalhos citados, refazer as porcentagens. Apesar disto, também ocorreu a correlação inversa entre tamanho da posse e porcentagens de alforriados no estudo de Guedes. Márcio Soares comparou as proporções das alforrias de acordo com as faixas de tamanho de rique- 
za. Isto tornou mais difícil um cotejamento com os estudos que abordam este tema, que se baseiam em faixas de tamanho de posses. No entanto, procuramos na Tabela $\mathbf{V}$ uma aproximação. Consideramos, nos dois períodos estudados pelo autor, que os indivíduos mais ricos foram aqueles descritos na última faixa, neste caso a de maior riqueza; e os mais pobres os arrolados na primeira faixa de fortuna. Na faixa intermediária, e somente nela, procedemos a um novo cálculo, cujas cifras se encontram na Tabela V. Cabe ressaltar que, a par de todos esses cálculos, uma consideração que deve ser feita sobre o estudo de Soares é a de que em sua pesquisa também houve uma correlação inversa entre as faixas de fortuna e a proporção de alforrias, ou seja, os mais ricos alforriaram proporcionalmente menos do que os menos abastados.

Tabela V

Alforrias na morte do senhor, por "testadores libertantes" em Juiz de Fora em comparação com quatro localidades do Sudeste escravista

\begin{tabular}{|c|c|c|c|c|c|c|c|}
\hline $\begin{array}{l}\text { Tamanho das } \\
\text { posses }\end{array}$ & $\begin{array}{l}\text { Juiz de } \\
\text { Fora } \\
\text { (MG) } \\
\text { (XIX) }\end{array}$ & $\begin{array}{c}\text { Comarca } \\
\text { do Rio das } \\
\text { Velhas (MG) } \\
(1720-1784)\end{array}$ & $\begin{array}{c}\text { Campinas } \\
(\mathrm{SP}) \\
(1836- \\
1845)\end{array}$ & $\begin{array}{c}\text { Campinas } \\
\text { (SP) } \\
(1860- \\
1871)\end{array}$ & $\begin{array}{c}\text { Porto } \\
\text { Feliz (SP) } \\
(1788- \\
1878)\end{array}$ & $\begin{array}{c}\text { Campos } \\
\text { (RJ) } \\
(1735- \\
1807)\end{array}$ & $\begin{array}{c}\text { Campos } \\
\text { (RJ) } \\
(1808- \\
1830)\end{array}$ \\
\hline $\begin{array}{c}\text { Pequena } \\
\text { (1-20 cativos) }\end{array}$ & $71,4 \%$ & $31,9 \%$ & $36,8 \%$ & $43,5 \%$ & $30,4 \%$ & $26,7 \%$ & $70,8 \%$ \\
\hline $\begin{array}{c}\text { Média } \\
\text { (21-40 cativos) }\end{array}$ & $0,0 \%$ & $15,4 \%$ & $52,1 \%$ & $5,2 \%$ & $15,6 \%$ & $17,2 \%$ & $26,2 \%$ \\
\hline $\begin{array}{c}\text { Grande } \\
(41+\text { cativos })\end{array}$ & $4,0 \%$ & $1,8 \%$ & $2,5 \%$ & $4,6 \%$ & $6,4 \%$ & $4,9 \%$ & $6,8 \%$ \\
\hline
\end{tabular}

Fonte: PAIVA, Eduardo França. Escravidão e universo cultural na colônia, p.175; FERRAZ, Lizandra Meyer. Testamentos, alforrias e liberdade, p.65-66; GUEDES, Roberto. Egressos do cativeiro, p.192 e SOARES, Márcio de Sousa. A remissão do cativeiro, p.135.

O estudo das alforrias em todos os inventários, ou seja, aqueles com e sem testamentos, permite outro refinamento da análise. Na Tabela VI, os números e percentagens mudam, porém as pequenas posses continuam a alforriar proporcionalmente mais do que as grandes, respectivamente $24,4 \%$ e $2,1 \%$.

A comparação aqui pode ser feita com os estudos de Paiva para a Comarca do Rio das Mortes e com a pesquisa de Ferraz sobre dois períodos em Campinas. No que diz respeito às percentagens dos alforriados pelos senhores de maior cabedal, nossa cifra se encontra bem no meio da variação assinalada pelos resultados dos pesquisadores citados (Tabela VII). 
Tabela VI

Alforrias na morte do senhor em todos os inventários com e sem testamentos: famílias Dias Tostes, Barbosa Lage e Paula Lima, século XIX

\begin{tabular}{ccccccccccc}
\hline Escravaria & $\begin{array}{c}\text { Inventários } \\
\text { com e sem } \\
\text { testamento }\end{array}$ & $\begin{array}{c}\text { Total de } \\
\text { escravos } \\
\text { possuídos }\end{array}$ & $\begin{array}{c}\text { Testado- } \\
\text { res que } \\
\text { libertaram }\end{array}$ & $\%$ & $\begin{array}{c}\text { Alfor- } \\
\text { rias em } \\
\text { testamento }\end{array}$ & $\%$ & $\begin{array}{c}\text { \% alforria- } \\
\text { dos na faixa } \\
\text { de posse }\end{array}$ \\
\hline $\begin{array}{c}\text { Pequena } \\
(1-20 \text { cativos })\end{array}$ & 04 & 21,0 & 41 & 3,7 & 02 & 28,6 & 10 & 34,5 & 24,4 \\
$\begin{array}{c}\text { Média } \\
(21-40 \text { cativos })\end{array}$ & 05 & 26,3 & 152 & 13,9 & 00 & 0,0 & 00 & 0,0 & 0,0 \\
$\begin{array}{c}\text { Grande } \\
(41+\text { cativos })\end{array}$ & 10 & 52,7 & 902 & 82,4 & 05 & 71,4 & 19 & 65,5 & 2,1 \\
Total & 19 & 100 & 1095 & 100 & 07 & 100 & 29 & 100 & 2,6 \\
\hline
\end{tabular}

Fonte: Inventários post-mortem do AHUFJF e do APMPAJS (Barbacena).

Tabela VII

Alforrias na morte do senhor, em inventários com e sem testamento: Juiz de Fora em comparação com duas localidades do Sudeste escravista.

\begin{tabular}{ccccc}
\hline Tamanho das posses & $\begin{array}{c}\text { Juiz de Fora } \\
(\mathrm{XIX)}\end{array}$ & $\begin{array}{c}\text { Rio das Mortes (MG) } \\
(1716-1789)\end{array}$ & $\begin{array}{c}\text { Campinas (SP) } \\
(1836-1845)\end{array}$ & $\begin{array}{c}\text { Campinas (SP) } \\
(1860-1871)\end{array}$ \\
\hline Pequena (1-20 cativos) & $24,4 \%$ & $9,1 \%$ & $9,2 \%$ & $16,7 \%$ \\
Média (21-40 cativos) & $0,0 \%$ & $2,9 \%$ & $10,0 \%$ & $3,1 \%$ \\
Grande (41 + cativos) & $2,1 \%$ & $3,9 \%$ & $0,9 \%$ & $3,4 \%$ \\
\hline
\end{tabular}

Fonte: PAIVA, Eduardo França. Escravidão e universo cultural na colônia, p.176; FERRAZ, Lizandra Meyer. Testamentos, alforrias e liberdade, p.65-66. Aqui cabem as mesmas ressalvas feitas na Tabela V, no que diz respeito aos cálculos feitos a partir dos trabalhos de Paiva e Ferraz.

Considerando-se as alforrias concedidas em testamento, mais aquelas dadas no decorrer do processo de inventário, eleva-se o número de escravistas que libertaram (Tabela VIII). Neste aspecto, os grandes proprietários também se sobressaíram, com relação aos senhores possuidores de pequenas posses. A agregação dessas alforrias no decorrer do inventário elevou o número de manumissões feitas por aquelas famílias. De um total de 29 em inventário, com e sem testamento, passaram para 52. Em números absolutos, os que mais contribuíram para o primeiro passo rumo à liberdade novamente foram os senhores de maior riqueza. Porém, apesar de terem mantido a mesma percentagem de alforrias, os senhores com menor riqueza continuaram a superar os mais ricos no que diz respeito à proporção de seus escravos alforrias, respectivamente, $24,4 \%$ contra $4,2 \%$. Os médios proprietários, que alforriaram apenas no decorrer do inventário, libertaram 
2,6\% do total de seus escravos. Não foi possível comparar os resultados da Tabela VIII com os de outras regiões, pois não existem trabalhos com dados disponíveis (discriminados por faixa de tamanho da posse) sobre alforrias dadas no decorrer do processo de inventário.

\section{Tabela VIII}

Alforrias na morte do senhor em inventários com e sem testamentos e no decorrer do inventário, Dias Tostes, Barbosa Lage e Paula Lima, século XIX

\begin{tabular}{cccccc}
\hline Escravaria & $\begin{array}{c}\text { Número de } \\
\text { Alforrias em } \\
\text { testamento }\end{array}$ & $\begin{array}{c}\text { Número de Alforrias } \\
\text { no decorrer do } \\
\text { inventário }\end{array}$ & $\begin{array}{c}\text { Total de Alforrias } \\
\text { em testamento e no } \\
\text { decorrer do inventário }\end{array}$ & $\%$ & $\begin{array}{c}\text { \% de alforriados na } \\
\text { faixa de posse }\end{array}$ \\
\hline Pequena & 10 & 00 & 10 & 19,2 & 24,4 \\
Média & 00 & 04 & 04 & 7,7 & 2,6 \\
Grande & 19 & 19 & 38 & 73,1 & 4,2 \\
Total & 29 & 23 & 52 & 100 & 4,7 \\
\hline
\end{tabular}

Fonte: Inventários post-mortem do AHUFJF e do APMPAJS (Barbacena). Os senhores que alforriaram no decorrer do inventário foram Dona Maria Antonia de Oliveira, 04 cativos; Dona Cândida Maria Carlota, 06 escravos e Dona Francisca Benedicta de Miranda Lima, 13 cativos.

Uma explicação possível para esses resultados é aquela dada por Soares: o relacionamento entre senhores e escravos era mais próximo nas pequenas posses, tanto física quanto culturalmente (havia relativamente menos africanos), do que nas grandes propriedades, o que levava mais senhores a alforriar em testamento. Outra é a hipótese de Slenes: os pequenos proprietários eram bem mais vulneráveis do que os grandes (tinham menos recursos para lidar com fugas e outros atos de rebeldia) e, portanto, tinham que ceder mais na negociação com seus escravos, no caso abrindo mais perspectivas para eles ganharem a alforria em testamento.

O que procuramos demonstrar neste artigo foi a necessidade de se utilizar vários tipos de fontes (inventários, registros paroquiais, testamentos, cartas de liberdade, etc) para melhor se compreender os processos de alforria, e também a possibilidade de por meio deste procedimento metodológico se chegar a números mais fidedignos com relação ao número de alforrias concedidas/conquistadas. A análise dos atos legais que possibilitaram a alforria dos cativos pertencentes àquelas três famílias da elite possibilitou perceber que as cartas de liberdade registradas em cartório não foram o único instrumento utilizado para a consecução da liberdade, neste aspecto também se mostraram importantes as alforrias em testamento e no correr do inventário. Por fim, constatamos que em Juiz de Fora, assim como em outras localidades houve uma tendência de que os maiores possuidores de cativos alforriassem proporcionalmente menos do que os pequenos e médios senhores de escravos. 